\title{
Pemrograman Sistem Kontrol Untuk Mendeteksi Gangguan Dan Mengoreksi Format Tampilan Video Wall Secara Otomatis
}

\author{
Hans Fernandi Halim ${ }^{1}$, Yohanes Calvinus ${ }^{1}$
}

\begin{abstract}
Video wall is a system that some media displays combined as close as possible in a matrix (column and row) to make a bigger display. Sometimes the display does not show perfectly due to of power supply issue in one of the monitors. The purpose of this design is to program a control system that not only can operate the video wall but also can detect power supply issue and reformat the display area template automatically. This programming uses Netlinx studio software and TPdesign4. The hardware is AMX Netlinx Integrated Controller NI3100, Modero View Point MVP-9000i, Kramer Matrix Swticher VS-66HDCP and Monitor LG 47WV50. Subprogram which added is "Deteksi Gangguan" Subprogram, "Koreksi Format Tampilan" Subprogram and "Notifikasi SMS" Subprogram. The operating process of these programs are the master controller sends ASCII code to each monitor then the monitor gives a feedback which indicates the power supply status. If power supply detected as an issue then "Koreksi Format Tampilan" subprogram will be executed and the "Notifikasi SMS" will also be executed. The test results show that the subprograms works perfectly as designed, but it needs some program modification to apply it to the whole system.
\end{abstract}

Keywords: power supply issue, video wall, control system, display area template.

\begin{abstract}
ABSTRAK: Video wall adalah suatu sistem dimana beberapa media tampilan digabungkan sedekat mungkin dalam sebuah matriks (kolom dan baris) untuk membentuk satu tampilan yang besar. Terkadang hasil tampilan tidak selalu sesuai dengan kehendak pengguna yang disebabkan adanya gangguan catudaya pada salah satu monitor yang bersangkutan. Tujuan dari perancangan program ini adalah merancang sebuah program sistem kontrol yang tidak hanya mengendalikan operasi video wall, tetapi juga mampu mendeteksi adanya gangguan dan melakukan koreksi format tampilan secara otomatis.Perancangan program ini menggunakan perangkat lunak Netlinx Studio dan TPDesign4. Perangkat keras yang digunakan adalah AMX Netlinx Integrated Controller NI3100, Modero View Point MVP-9000i, Kramer Matrix Swticher VS-66HDCP dan Monitor LG 47WV50. Subprogram yang ditambahkan adalah subprogram Deteksi Gangguan, Subprogram Koreksi Format Tampilan, dan Subprogram Notifikasi SMS. Proses operasi dari program ini adalah pengendali induk mengirimkan kode ASCII ke setiap monitor kemudian monitor akan memberikan umpan balik keadaan dari catudaya, apabila ditemukan adanya gangguan, subprogram Koreksi Format Tampilan mengubah format tampilan video wall sesuai dengan ketentuan serta subprogram Notifikasi SMS mengirimkan SMS kepada teknisi terkait untuk memberitahukan bahwa video wall mengalami gangguan. Hasil pengujian subprogram menunjukan kesesuaian fungsi operasi dengan rancang bangun. Namun dibutuhkan sedikit modifikasi program ketika diaplikasikan ke sistem secara keseluruhan untuk dapat melakukan fungsinya dengan baik.
\end{abstract}

Kata kunci: gangguan catu daya, video wall, sistem kontrol, format tampilan.

\section{PENDAHULUAN}

$\mathrm{S}$ emakin majunya era digital zaman ini, banyak cara yang bisa dilakukan oleh beberapa pelaku usaha untuk mempromosikan barang atau jasa yang dijual secara lebih efektif. Salah satunya dengan menggunakan suatu media yang memiliki tampilan berskala besar dan lebih hidup dibandingkan cara konvensional. Oleh karena itu, dewasa ini telah berkembang suatu sistem yang dinamakan video wall. Di Indonesia pun, semakin banyak pelaku usaha yang menginvestasikan uangnya untuk membuat sistem ini sebagai media promosi. Sistem video wall memungkinkan pelaku usaha untuk menampilkan informasi multimedia yang telah dipersiapkan oleh komputer. Informasi tersebut kemudian ditransmisikan ke video wall dan dikendalikan oleh sistem kontrol yang telah diprogram.

Namun pada umumnya hasil tampilan tidak selalu sesuai dengan kehendak pelaku usaha. Hal ini terjadi karena adanya gangguan pada salah satu monitor dari video wall yang disebabkan oleh tidak berfungsinya catu daya secara sempurna pada monitor bersangkutan. Untuk mengatasi gangguan ini, pelaku usaha harus mengubah format tampilan video wall secara manual. Untuk memperbaiki pola operasi tersebut, dalam perancangan ini, dirancanglah suatu program sistem kontrol yang dapat mendeteksi dan mengoreksi masalah tersebut secara otomatis sesuai dengan protokol devais yang bersangkutan. Dengan demikian kinerja sistem ini dapat lebih efisien, lebih handal sekaligus mengurangi beban dan waktu operator.

Tujuan dari perancangan program ini adalah merancang sebuah program sistem kontrol yang tidak hanya mengendalikan operasi video wall, tetapi juga mampu mendeteksi adanya gangguan catu daya dan melakukan koreksi format tampilan secara otomatis. Program ini memiliki batasan berupa, tidak adanya hardware yang dirancang, sistem ini hanya memaksimalkan fungsi pengendali induk dengan menambahkan kode untuk program deteksi dan koreksi secara otomatis.

Video wall adalah suatu sistem tampilan yang terdiri dari sejumlah media tampilan yang digabungkan serapat mungkin dalam sebuah matriks (kolom dan baris) untuk membentuk satu tampilan bermodus jamak yang lebih besar bandingkan dengan monitor tunggal [1]. Seperti namanya, video wall biasanya dipasang di dinding dengan orientasi Landscape atau Portrait. Ukuran video wall bervariasi mulai dari 2 unit monitor sampai dengan 664 unit monitor yang merupakan rekor dunia Guinness sebagai video wall terbesar di dunia terpasang di Suntec Singapore [2]. Terdapat 3 arsitektur sistem video wall dalam menyalurkan sinyal sumber diantaranya Centralized Video Wall Processing, Distributed Video Wall Processing dan Hybrid Video Wall Processing [3]. Arsitektur Centralized Video Wall Processing adalah arsitektur video wall dengan sinyal input PC yang dikelola 1 unit video wall processor sebelum ditampilkan di media tampilan. Arsitektur ini sangat ideal apabila sumber sinyal dan media

${ }^{1}$ Program Studi Teknik Elektro, Fakultas Teknik, Universitas Tarumanagara 

tampilan terletak didalam 1 jaringan prosesor dan tidak dibutuhkan sebuah sistem kontrol terpsisah karena video wall processor sudah mampu mengendalikan operasional sistem. Gambar 1 menunjukan Arsitektur Centralized Video Wall Processing.

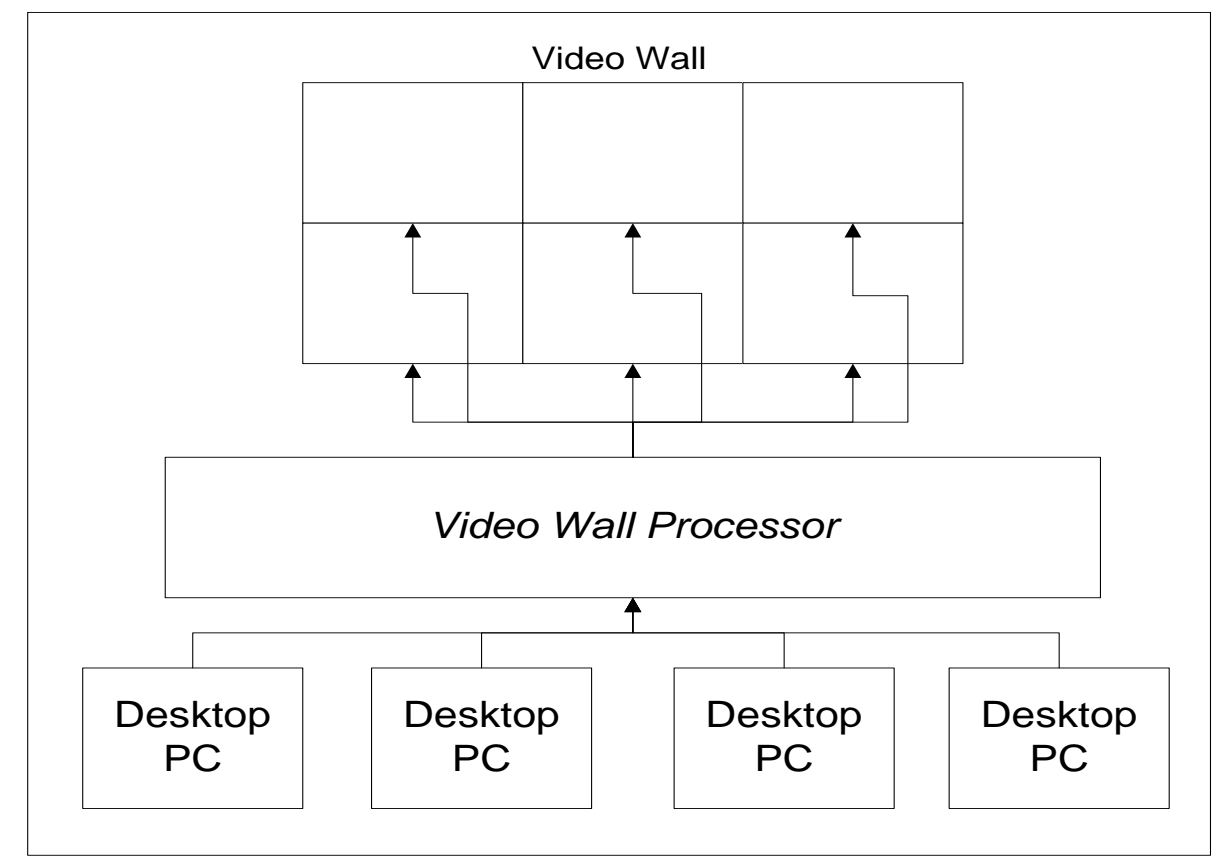

- Gambar 1. Arsitektur Centralized Video Wall Processing.

Arsitektur Distributed Video Wall Processing adalah arsitektur video wall yang sinyal input di salurkan melalui beberapa modul. Terdapat 2 bentuk arsitektur Distributed Video Wall Processing yaitu Matrix Switcher Distribution dan Network Distribution. Dalam bentuk Matrix Switcher Distribution, setiap sumber sinyal disalurkan melalui sebuah matrix switcher ke seluruh atau sebagian media tampilan. Gambar 2 menunjukkan arsitektur Matrix Switcher Distribution. Dalam bentuk Network Distribution, setiap sumber sinyal disalurkan melalui Network ke seluruh atau sebagian media tampilan. Sebelum disalurkan, sinyal PC di hubungkan ke input modules yang mengubah sinyal untuk di salurkan melalui network dan akan diterima oleh output modules untuk diubah kembali ke bentuk semula untuk ditampilkan ke media tampilan. Gambar 3 menunjukkan arsitektur Network Distribution.

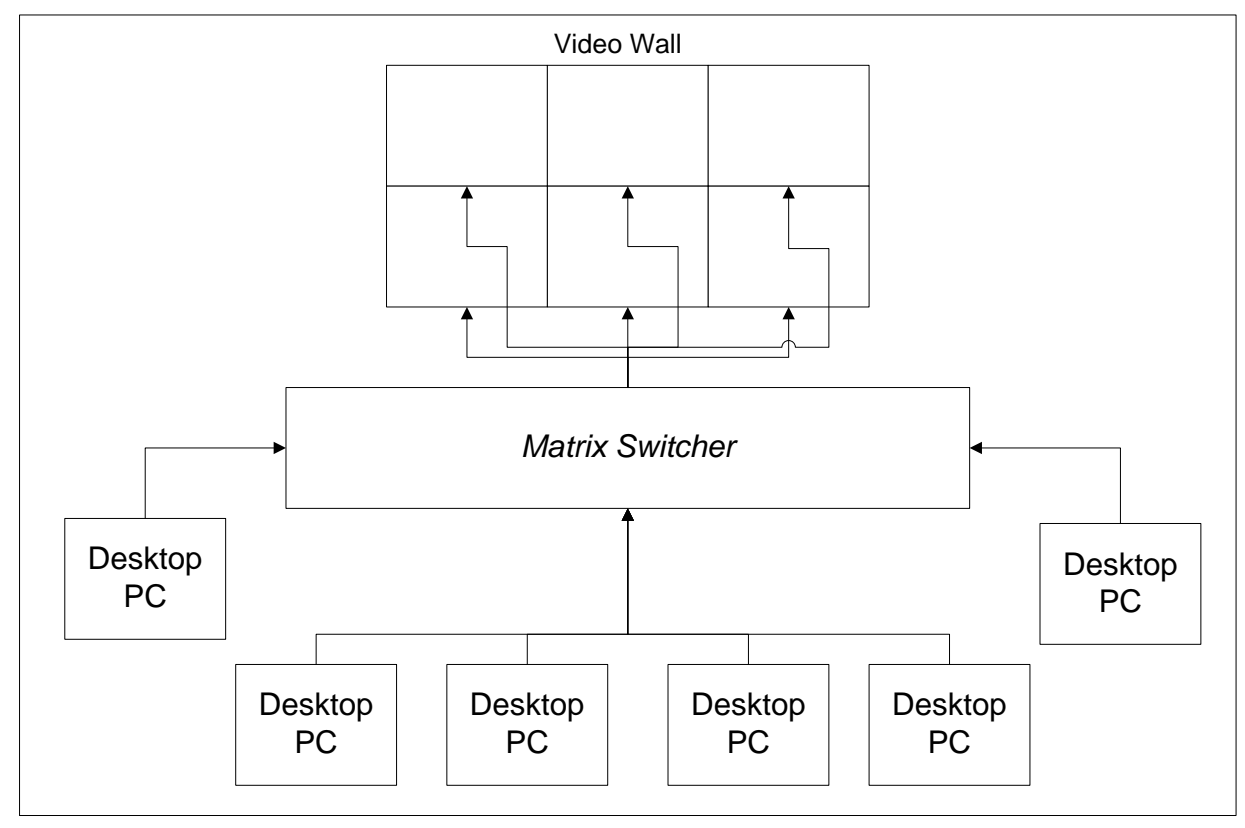

- Gambar 2. Arsitektur Matrix Switcher Distribution. 


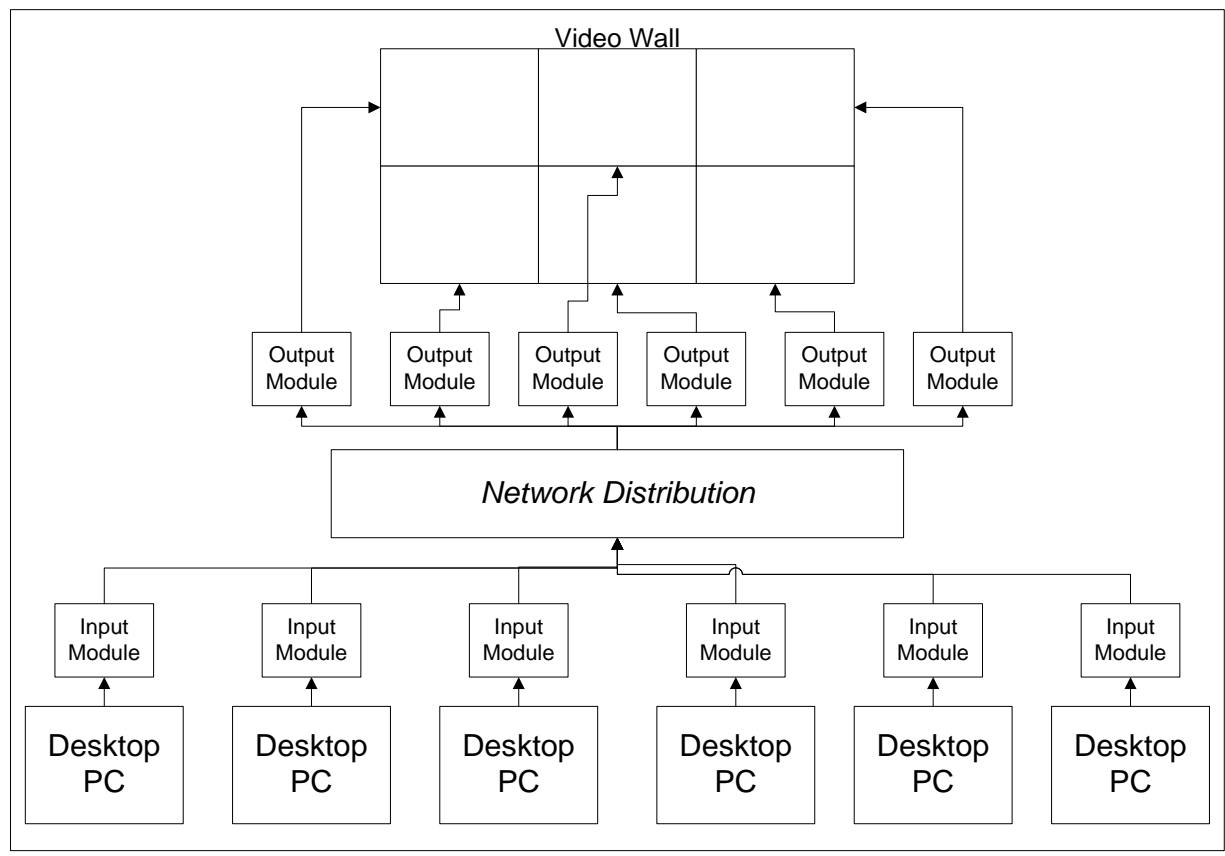

- Gambar 3. Arsitektur Network Distribution

Hybrid Video Wall Processing merupakan gabungan dari Arsitektur Centralized dan Distributed Video Wall Processing. Sumber sinyal terbuhung dengan modul yang menyalurkan sinyal tersebut melalui network ke video wall processor. Arsitektur ini sangat ideal apabila sinyal sumber berada di luar jaringan video wall processor. Gambar 4 menunjukkan arsitektur Hybrid Video Wall Processing.

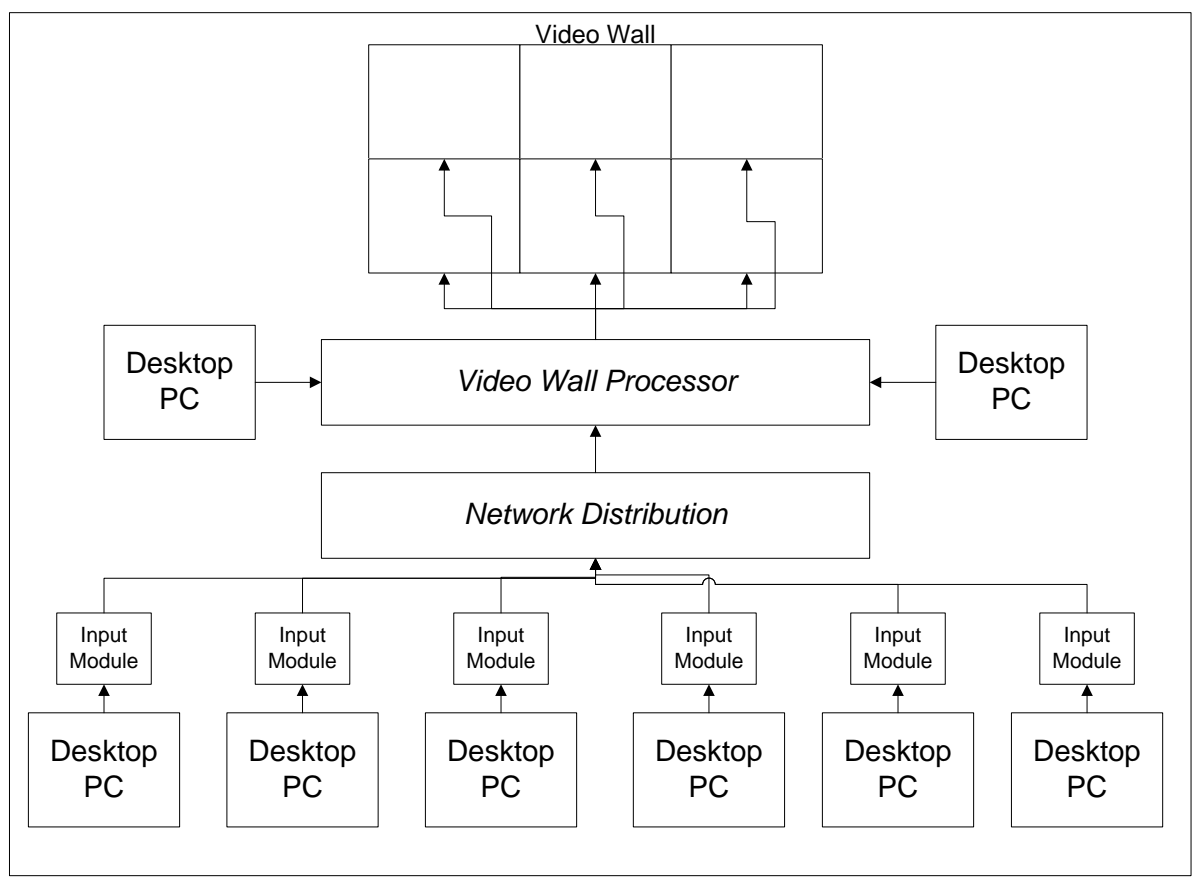

- Gambar 4. Arsitektur Hybrid Video Wall Processing.

\section{METODE PERANCANGAN}

Perangkat keras dan perangkat lunak yang digunakan dalam perancangan ini yaitu dengan dimulai dari pemilihan komponen Pengendali induk menggunakan AMX NI-3100 Netlinx ${ }^{\circledR}$ Integrated Controller. Beberapa fitur pengendali induk ini yang juga menjadi alasan pemilihan perangkat ini adalah memiliki:

- 7 Serial Port RS232 untuk menggendalikan perangkat-perangkat yang digunakan

- 8 Relays , 8 IR ports, 8 Digital I/O Ports

- 2 komunikasi Network: AxLink dan Ethernet (TCP/IP)

- 64MB RAM, 2 GB

- Compact Flash (CF) 
Touchpanel menggunakan AMX Modero ${ }^{\circledR}$ MVP-9000i. Beberapa fitur dari MVP-9000i yang juga menjadi alasan pemilihan perangkat ini adalah memiliki:

- $802.11 \mathrm{a} / \mathrm{b} / \mathrm{g}$ wifi

- Umur baterai sampai dengan 5 jam untuk penggunaan secara terus menerus dan 3 hari untuk idle.

- Resolusi 800 x 480

- LED Backlid display

- Kedalaman warna 24-bit

Monitor menggunakan LG Signage Monitor 47 inch model 47WV70. Beberapa fitur monitor ini yang juga menjadi alasan pemilihan monitor adalah:

- Jarak Bezel to Bezel yang kecil (6,3mm) hal ini menjadikan informasi yang ditampilkan menjadi lebih efektif dibanding monitor biasa yang beredar di pasaran.

- Konsumsi daya yang relatif lebih rendah (Maximum 220W)

- Memiliki Tiling Mode hingga 15 x 15. tiling mode adalah fitur di mana monitor dapat mengambil 1 per $\mathrm{N}$ ( $\mathrm{N}$ = banyaknya monitor) bagian dari 1 tampilan yang utuh. contoh: untuk ukuran $3 \times 2,1$ monitor mengambil seperenam bagian dari keseluruhan tampilan.

- Resolusi 1920 x 1080

- input port: 15pin D-sub, Komponen, HDMI, DVI

- Dapat dikontrol melalui Serial Port RS232.

Matrix switcher menggunakan Kramer 6x6 DVI Matrix Switcher VS-66HDCP. Beberapa fitur Matrix Switcher ini yang juga menjadi alasan pemilihan perangkat ini adalah:

- Mendukung High-Bandwidth Digital Content Protection (HDCP)

- Memiliki 6 Input dan 6 Output

- Resolusi sampai dengan 1920 x 1200

- Bandwith 1,65Gbps

- Dapat dikontrol melalui Serial Port RS232.

Modem GSM menggunakan Wavecom M1306B. Beberapa fitur Modem GSM ini yang juga menjadi alasan pemilihan perangkat ini adalah:

- Mendukung komunikasi Serial RS232

- Menggunakan protokol GSM 07.05 dan 07.07 AT Commands

- Mendukung fitur Short Messages Services (SMS)

Software untuk memprogram pengendali induk menggunakan Netlinx Studio Versi 3.3.1.525. NetLinx Studio menggunakan bahasa pemrograman NetLinx yang didesain untuk meningkatkan fungsi bus prosesor dan merupakan modifikasi dari bahasa pemrograman Axcess. Hubungan antara bahasa NetLinx dan Axcess sama dengan hubungan antara bahasa $\mathrm{C}++$ dan $\mathrm{C}$, di mana $\mathrm{C}++$ merupakan peningkatan dari bahasa $\mathrm{C}$. Bahasa NetLinx mempunyai beberapa fungsi dan perintah baru untuk meningkatkan kecepatan dan efisiensi kerja alat-alat multimedia yang dipakai dewasa ini.

Software untuk mendesain GUI touch panel menggunakan TPDesign4 Versi 3.3.0 Build 672. TPDesign4 (Touch Panel Design) adalah perangkat lunak yang digunakan dalam perancangan GUI untuk touchpanel AMX Generasi 4 (G4). Perangkat lunak ini mempunyai semua fungsi yang dibutuhkan untuk mendefinisikan GUI agar dapat berkomunikasi dengan pengendali induk. Untuk menjalankan fungsi tersebut tersedia workspace yang terdiri dari pages dan popup pages. Pages merupakan halaman utama dari GUI, popup pages merupakan halaman pendukung halaman utama. Di dalam pages dan popup pages terdapat button yang ditandai dengan channel code untuk menjalankan fungsi yang telah ditentukan. Selain itu, terdapat message box yang ditandai dengan address code untuk menampilkan text yang dikirim oleh pengendali induk. 


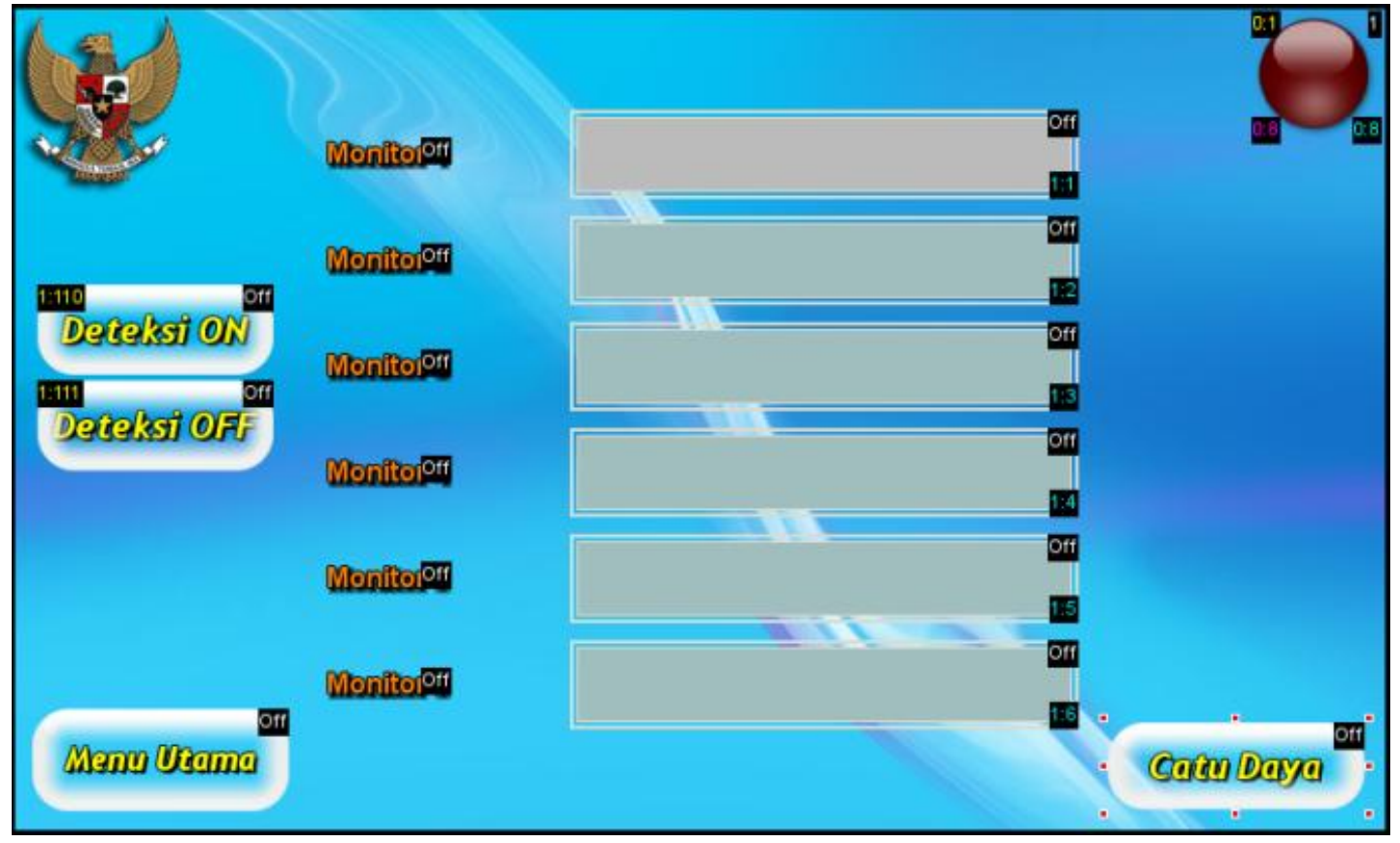

- Gambar 5. Tampilan Utama GUI

Realisasi rancangan program terdiri dari langkah penyesuaian dalam penyusunan GUI touchpanel, penyusunan subprogram khusus untuk deteksi gangguan dan subprogram khusus untuk koreksi atau penyesuaian format tampilan. Realisasi GUI dari touchpanel ini dilakukan dengan menggunakan perangkat lunak TP4 Design Gambar 5 merupakan tampilan utama GUI untuk pengaktifan program. Pemrograman pengendali induk dilakukan dengan menggunakan perangkat lunak Netlinx Studio. Pemrograman ini terdiri dari 3 subprogram yaitu subprogram deteksi gangguan, subprogram koreksi format tampilan dan subprogram notifikasi SMS. Cara kerja subprogram deteksi gangguan adalah secara berkala akan mengirimkan string berupa kode ASCII ke setiap monitor. Setelah mengirimkan kode tersebut, monitor akan segera memberi kode umpan balik berupa keadaan dari catu daya monitor tersebut. Gambar 6 menunjukan diagram alir Subprogram Deteksi Gangguan.

Setelah subprogram deteksi gangguan mendeteksi gangguan maka subprogram koreksi format tampilan akan dieksekusi. Perubahan format tampilan bergantung pada format tampilan awal dan posisi monitor yang mengalami gangguan catu daya. Gambar 7 menunjukan diagram alir perubahan format tampilan.

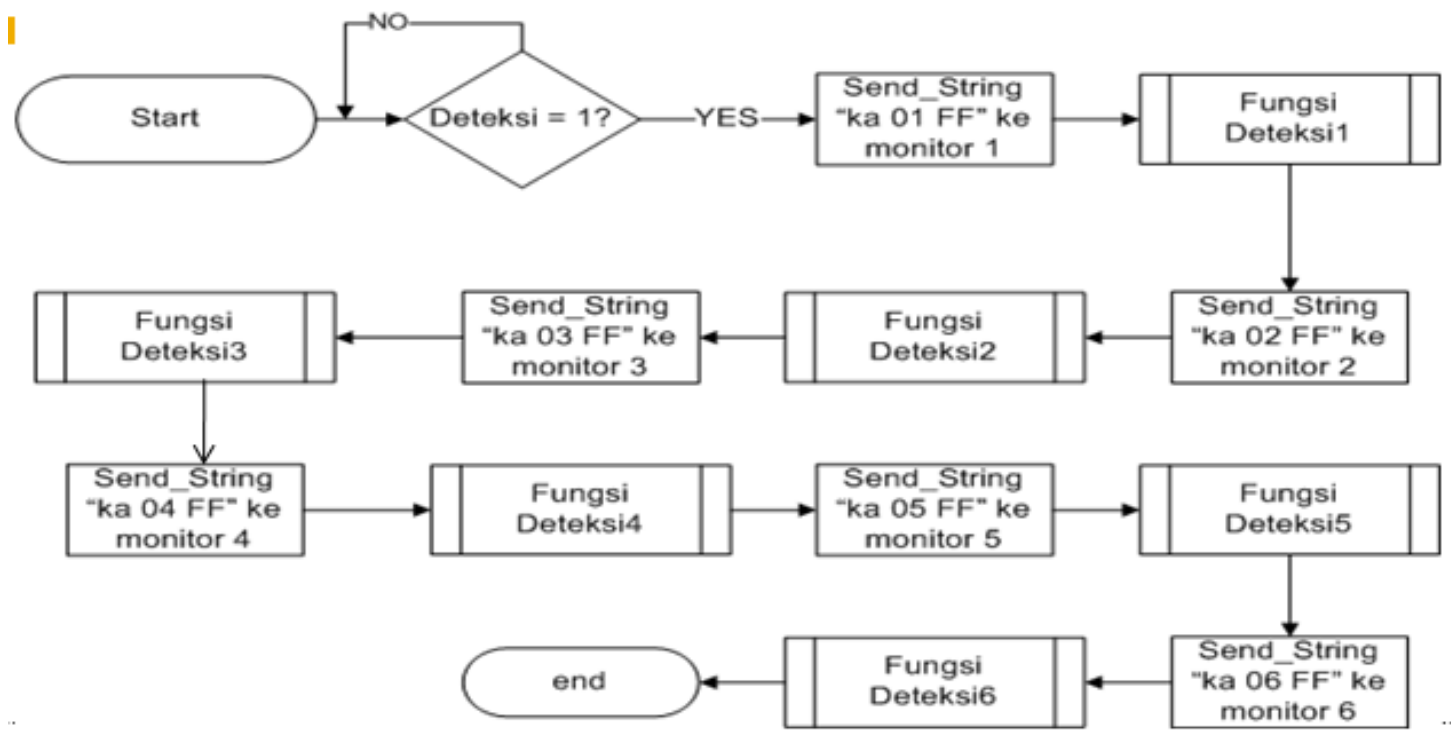

- Gambar 6. Diagram Alir Subprogram Deteksi Gangguan 


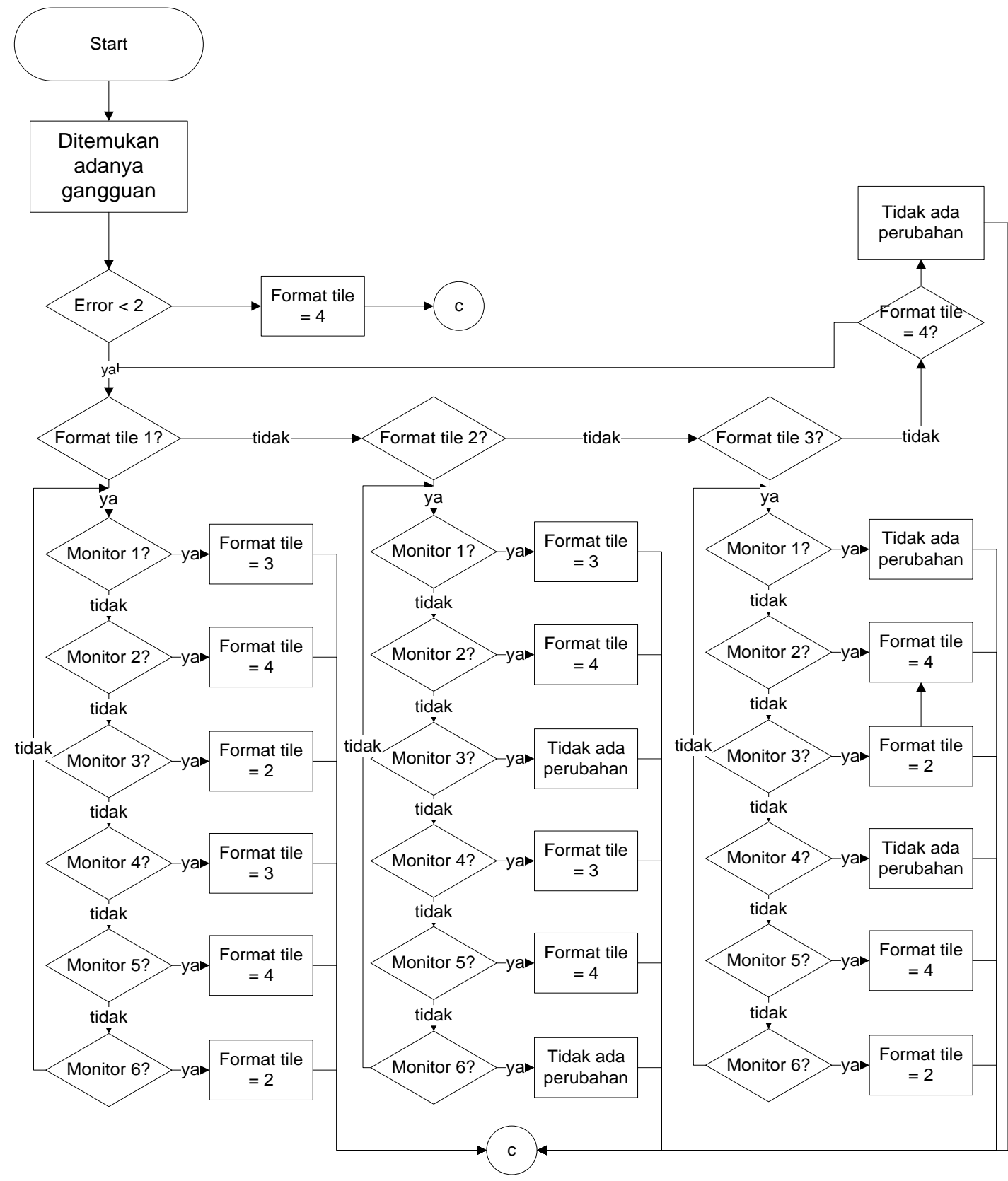

- Gambar 7. Diagram Alir Perubahan Format Tampilan

Bersamaan dengan dieksekusinya perubahan format tampilan tesebut, subprogram Notifikasi SMS pun diaktifkan. Subprogram ini mengirimkan SMS berupa pemberitahuan bahwa monitor dengan posisi yang bersangkutan mengalami gangguan kepada pemilik dan teknisi instalasi terkait. Gambar 8 menunjukan diagram alir subprogram Notifikasi SMS.

\section{HASIL DAN PEMBAHASAN}

Pengujian dan analisis sistem dilakukan secara bertahap pada subprogram tambahan yang terdiri dari subprogram deteksi gangguan, subprogram koreksi format tampilan dan subprogram notifikasi SMS. Dalam pengujian dan analisis tersebut diperiksa dan dinilai kesesuaian fungsi masing-masing subprogram dengan spesifikasi rancangannya. Analisis dan perbaikan yang perlu dilakukan bila ditemukan adanya ketidaksesuaian. Pengujian suprogram Deteksi Gangguan dilakukan dengan bantuan komputer, pengendali induk netlinx NI3100, touchpanel MVP-9000. Komputer dihubungkan ke pengendali induk dengan komunikasi serial RS232. Pengujian dilakukan 


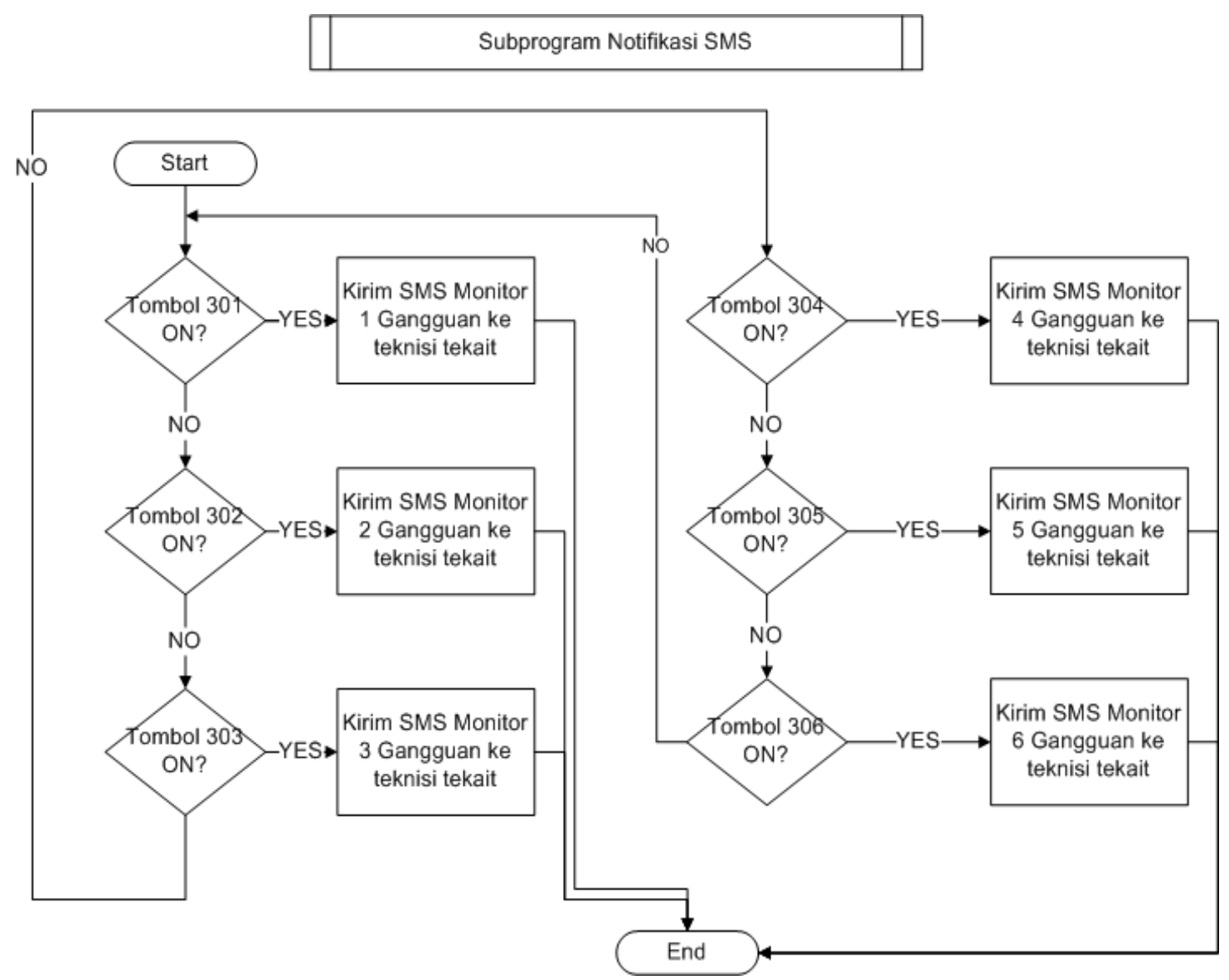

- Gambar 8. Diagram Alir Subprogram Notifikasi SMS

dengan mengaktifkan subprogram deteksi dan melihat data yang dikirim dan diterima pengendali induk dengan bantuan perangkat lunak Realterm, Debugging Netlinx Studio, VNC Viewer. Hasil pengujian dapat dilihat dalam gambar 9 sampai 11. Berdasarkan hasil pengujian subprogram deteksi gangguan ini telah diperoleh hasil verifikasi fungsi operasional dari subprogram deteksi gangguan yang sesuai dengan rancang bangun yang telah ditentukan.

RealTerm: Serial Capture Program 2.0.0.70

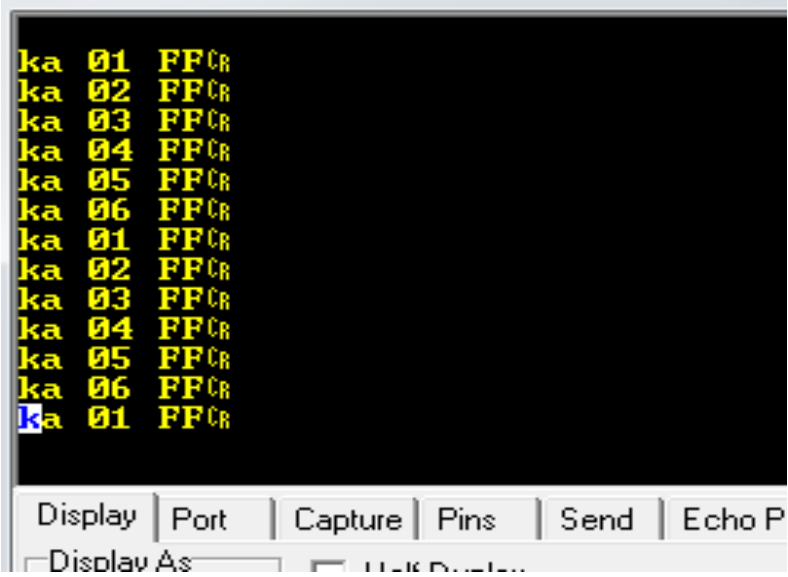

- Gambar 9. Hasil Pengujian Subprogram Deteksi - 1 


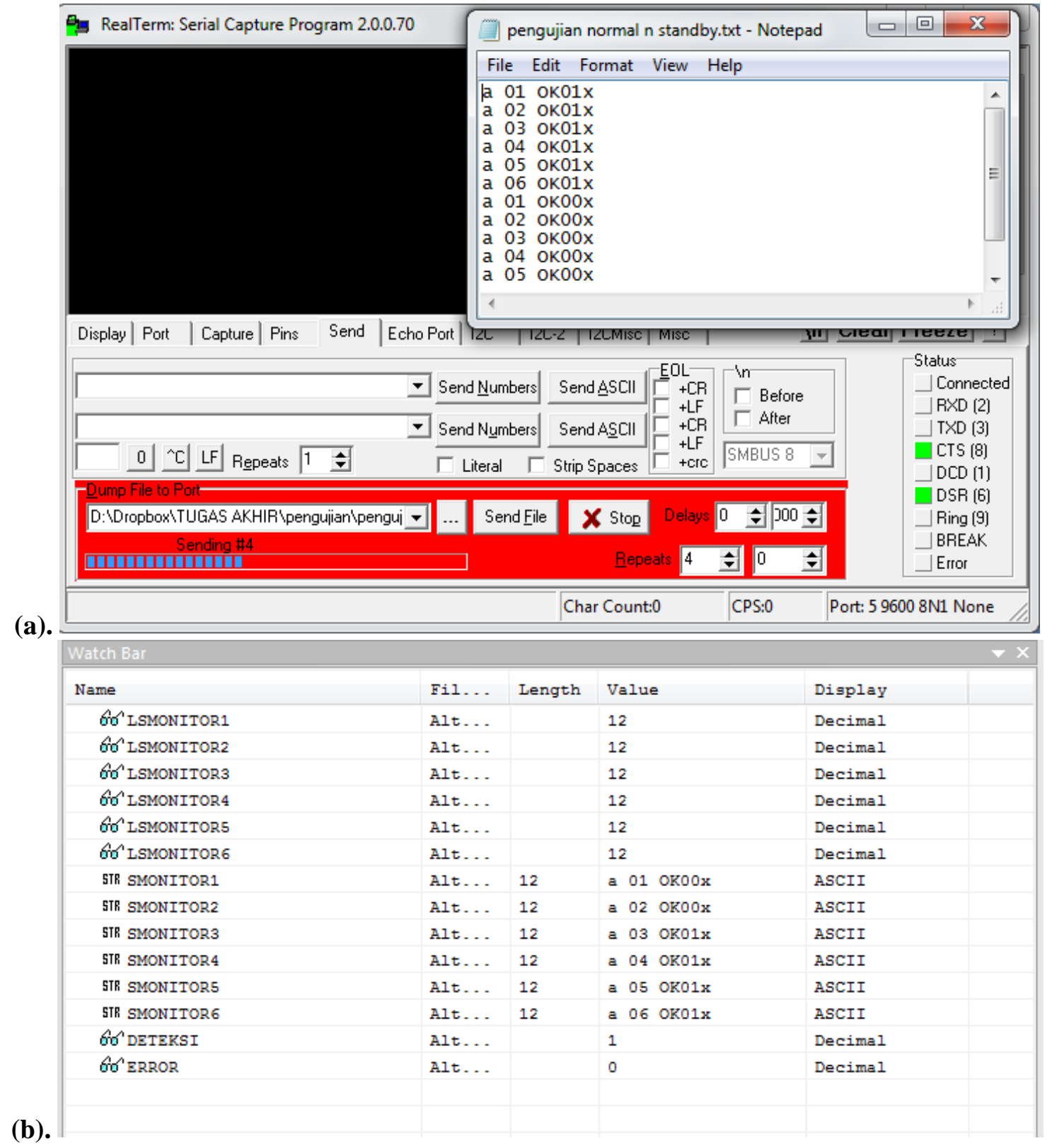

- Gambar 10. (a) Hasil Pengujian Subprogram Deteksi - 2

(b) Hasil Penquiian Subprogram Deteksi - 3

Pengujian Subprogram Koreksi Format Tampilan dilakukan dengan meneruskan langkah pengujian yang dijelaskan sebelumnya, yaitu mengirimkan kode monitor yang mengalami gangguan secara bergantian (monitor 1 sampai dengan monitor 6). Hasil pengujian dapat dilihat dalam gambar 13 dan 14. Tabel 1 menunjukan perubahan tile. Berdasarkan hasil pengujian subprogram koreksi format tampilan, dapat disimpulkan bahwa subprogram koreksi format tampilan dapat menjalankan fungsinya sesuai dengan ketentuan yang telah dirancang. 


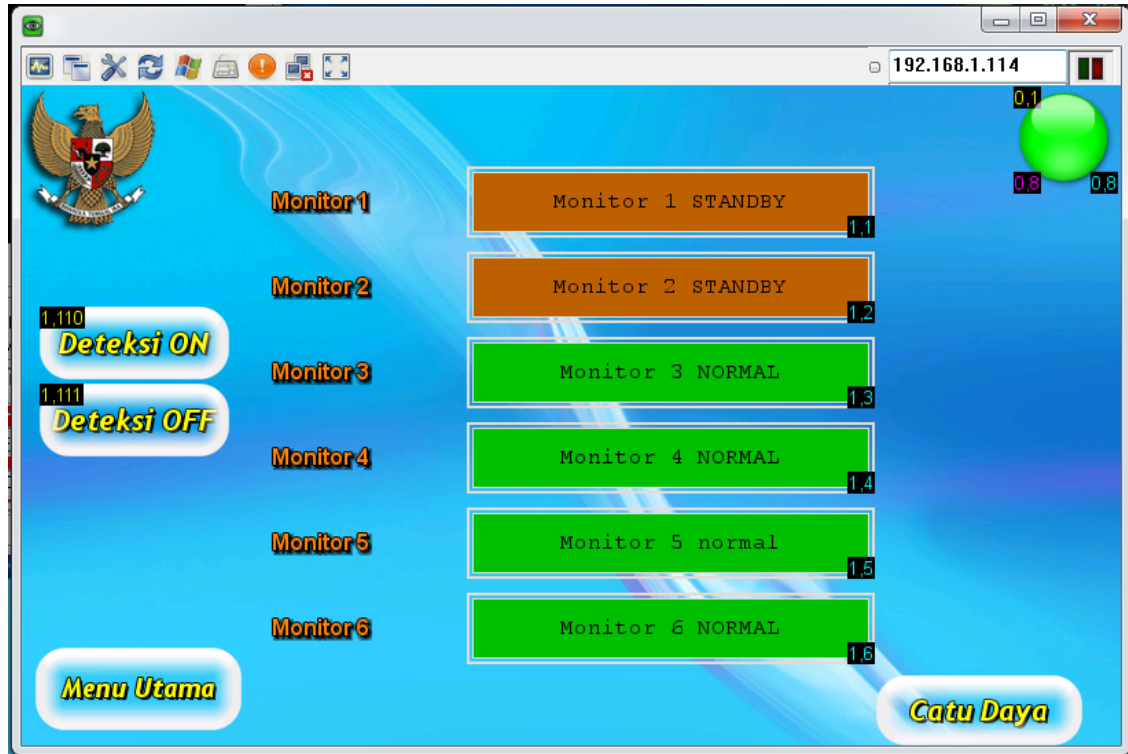

- Gambar 11. Hasil Pengujian Subprogram Deteksi - 4

\begin{tabular}{|c|c|c|c|}
\hline Name & Fil... & Length & Value \\
\hline 66'ERROR & Alt... & & 1 \\
\hline 66'TILE & Alt... & & 3 \\
\hline 66'DETEKSI & Alt... & & 1 \\
\hline 66'LSMONITOR1 & Alt... & & 12 \\
\hline 66'LSMONITOR2 & Alt... & & 16 \\
\hline $66^{\prime}$ LSMONITOR3 & Alt... & & 17 \\
\hline 66'LSMONITOR4 & Alt... & & 0 \\
\hline $66^{\prime}$ LSMONITOR5 & Alt... & & 16 \\
\hline 66'LSMONITOR6 & Alt... & & 10 \\
\hline STR SMONITOR1 & Alt... & 12 & a 01 OK01x \\
\hline STR SMONITOR2 & Alt... & 16 & a 02 OK01x \\
\hline STR SMONITOR3 & Alt... & 17 & a 03 OK01xa \\
\hline STR SMONITOR4 & Alt... & 0 & \\
\hline STR SMONITORS & Alt... & 16 & a 05 OK01x \\
\hline STR SMONITOR6 & Alt... & 10 & a 06 OK01x \\
\hline
\end{tabular}

- Gambar 12. Hasil Pengujian Subprogram Koreksi Format Tampilan - 1

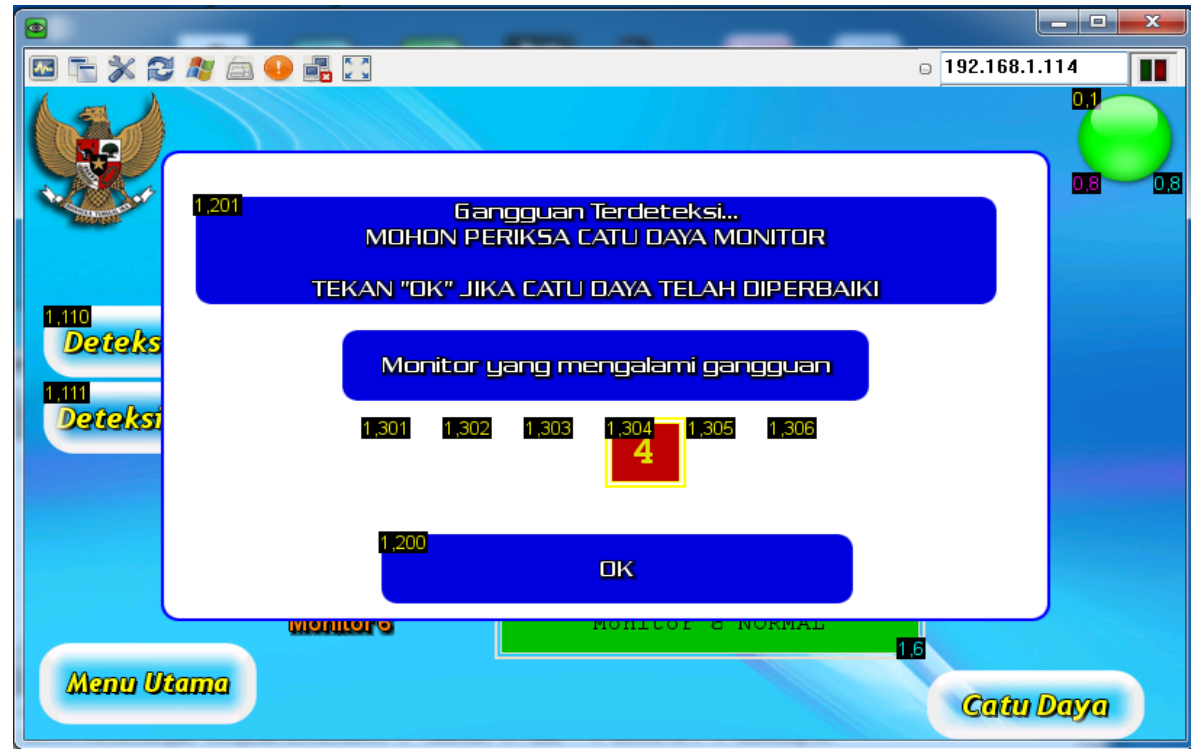

- Gambar 13. Hasil Pengujian Subprogram Koreksi Format Tampilan - 2 
- Tabel 1. Perubahan nilai tile sebelum dan sesudah koreksi

\begin{tabular}{|c|c|c|c|c|c|c|c|c|c|c|c|}
\hline $\begin{array}{l}\text { Tile } \\
\text { sebelum } \\
\text { koreksi }\end{array}$ & $\begin{array}{l}\text { Monitor } \\
\text { ID }\end{array}$ & $\begin{array}{l}\text { Tile } \\
\text { sesudah } \\
\text { koreksi }\end{array}$ & $\begin{array}{l}\text { Tile } \\
\text { Sebelum } \\
\text { Koreksi } \\
\end{array}$ & $\begin{array}{l}\text { Monitor } \\
\text { ID }\end{array}$ & \begin{tabular}{|l} 
Tile \\
Sesudah \\
Koreksi \\
\end{tabular} & \begin{tabular}{|l} 
Tile \\
Sebelum \\
Koreksi \\
\end{tabular} & $\begin{array}{l}\text { Monitor } \\
\text { ID }\end{array}$ & $\begin{array}{l}\text { Tile } \\
\text { Sesudah } \\
\text { Koreksi } \\
\end{array}$ & \begin{tabular}{|l|} 
Tile \\
Sebelum \\
Koreksi \\
\end{tabular} & $\begin{array}{l}\text { Monitor } \\
\text { ID }\end{array}$ & $\begin{array}{l}\text { Tile } \\
\text { Sesudah } \\
\text { Koreksi } \\
\end{array}$ \\
\hline & 1 & 3 & & 1 & 3 & & 1 & $\begin{array}{c}\text { Tidak } \\
\text { berubah }\end{array}$ & & 1 & $\begin{array}{c}\text { Tidak } \\
\text { berubah }\end{array}$ \\
\hline & 2 & 4 & & 2 & 4 & & 2 & 4 & & 2 & $\begin{array}{c}\text { Tidak } \\
\text { berubah }\end{array}$ \\
\hline & 3 & 2 & & 3 & $\begin{array}{c}\begin{array}{c}\text { Tidak } \\
\text { berubah }\end{array} \\
\end{array}$ & & 3 & 2 & & 3 & $\begin{array}{c}\begin{array}{c}\text { Tidak } \\
\text { berubah }\end{array} \\
\end{array}$ \\
\hline & 4 & 3 & & 4 & 3 & & 4 & $\begin{array}{c}\text { Tidak } \\
\text { berubah }\end{array}$ & & 4 & $\begin{array}{c}\text { Tidak } \\
\text { berubah }\end{array}$ \\
\hline & 5 & 4 & & 5 & 4 & & 5 & 4 & & 5 & $\begin{array}{c}\text { Tidak } \\
\text { berubah }\end{array}$ \\
\hline & 6 & 2 & & 6 & $\begin{array}{c}\text { Tidak } \\
\text { berubah }\end{array}$ & & 6 & 2 & & 6 & $\begin{array}{c}\text { Tidak } \\
\text { berubah }\end{array}$ \\
\hline
\end{tabular}

Pengujian subporgam Notifikasi SMS dilakukan menurut langkah pengujian yang dijelaskan sebelumnya, Dalam pengujian ini, digunakan sebuah telepon genggam untuk menerima SMS dari pengendali induk. Hasil pengujian ditunjukan dalam Gambar 14 A. Berdasarkan hasil pengujian subprogram notifikasi SMS, dapat disimpulkan bahwa subprogram ini dapat menjalankan fungsinya sesuai dengan ketentuan yang telah dirancang.

Pengujian program secara keseluruhan dilakukan dengan menerapkannya secara langsung ke sistem videowall berukuran $3(\mathrm{~h})$ x 2(v) sesuai dengan diagram blok yang ditunjukan dalam Gambar 14B. Gangguan diberikan dengan cara mematikan sumber listrik catudaya monitor secara disengaja dan mengaktifkan subprogram deteksi secara bersamaan. Pemberian gangguan dilakukan kesetiap monitor dengan kombinasi 3 format tampilan awal yaitu fullscreen, 3 zona kiri dan 3 zona kanan. Format tampilan picture by picture tidak diuji karena format tersebut dirancang tidak berubah apabila ditemukan adanya gangguan. Jeda waktu antara terjadinya gangguan sampai format tampilan monitor yang selesai dikoreksi diukur untuk menentukan selang waktu operasi dari program yang dirancang ini. Berdasarkan hasil pengujian dengan konfigurasi sistem dan program secara keseluruhan, dapat disimpulkan bahwa program ini dapat menjalankan fungsinya sesuai dengan ketentuan yang telah dirancang. Hasil pengujian dapat dilihat pada tabel 2.

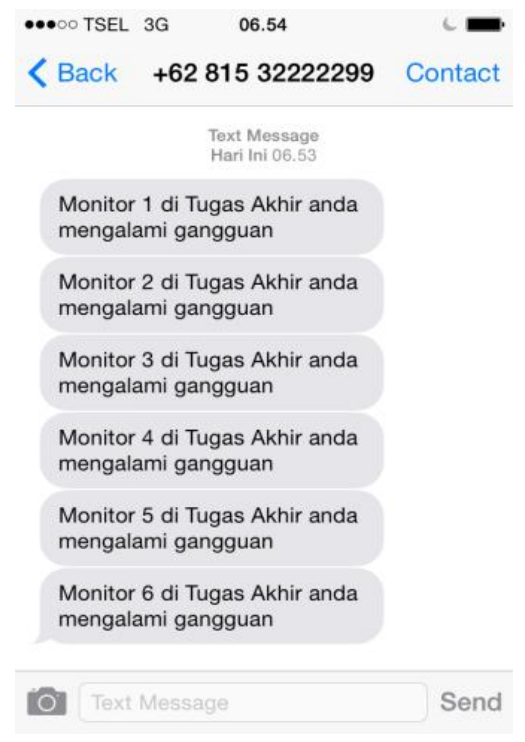

A.

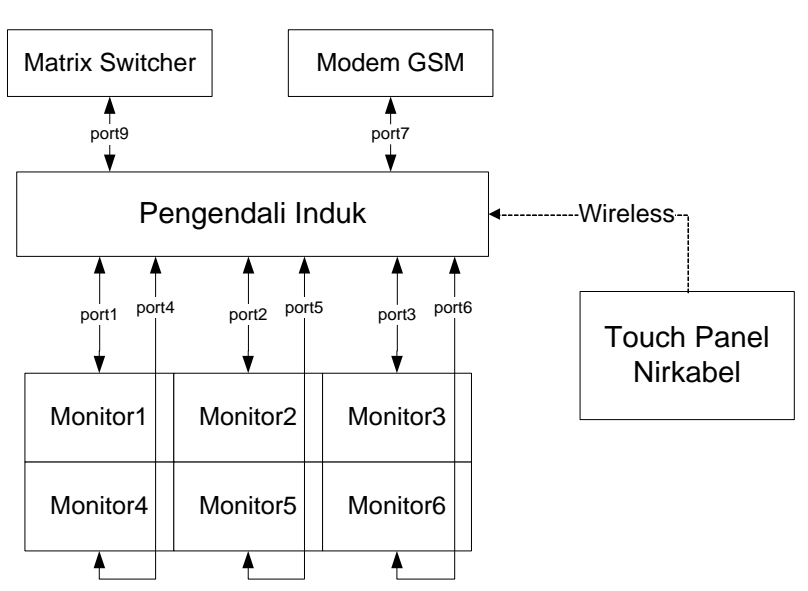

B.

- Gambar 14A. Hasil Pengujian Subprogram Notifikasi SMS

B. Diagram Blok Pengujian Program Secara Keseluruhan 
Pemrograman Sistem Kontrol Untuk Mendeteksi Gangguan Dan Mengoreksi Format Tampilan Video Wall Secara Otomatis

- Tabel 2. Hasil pengujian program secara keseluruhan

\begin{tabular}{|c|c|c|c|c|c|c|c|}
\hline \multirow{2}{*}{ Monitor ID } & \multirow{2}{*}{ tile awal } & \multicolumn{5}{|c|}{ Waktu yang dibutuhkan (detik) } & \multirow{2}{*}{ Rata-rata } \\
\hline & & 1 & 2 & 3 & 4 & 5 & \\
\hline \multirow{3}{*}{1} & 1 & 22.45 & 22.77 & 22.56 & 22.97 & 23 & 22.75 \\
\hline & 2 & 22.57 & 22.65 & 22.34 & 22.78 & 22.14 & 22.496 \\
\hline & 3 & 14.56 & 14.55 & 14.55 & 14.56 & 14.5 & 14.544 \\
\hline \multirow{3}{*}{2} & 1 & 15.11 & 15.21 & 15.33 & 15.22 & 15.24 & 15.222 \\
\hline & 2 & 15.23 & 14.95 & 15.03 & 15.01 & 14.88 & 15.02 \\
\hline & 3 & 14.97 & 15.45 & 15.55 & 15.12 & 15.14 & 15.246 \\
\hline \multirow{3}{*}{3} & 1 & 22.65 & 22.33 & 22.32 & 22.11 & 22.17 & 22.316 \\
\hline & 2 & 14.6 & 14.5 & 14.49 & 14.48 & 14.51 & 14.516 \\
\hline & 3 & 22.87 & 22.67 & 22.77 & 22.54 & 22.56 & 22.682 \\
\hline \multirow{3}{*}{4} & 1 & 22.34 & 22.54 & 22.01 & 22.99 & 22.14 & 22.404 \\
\hline & 2 & 22.56 & 22.13 & 22.13 & 22.45 & 22.65 & 22.384 \\
\hline & 3 & 14.5 & 14.51 & 14.49 & 14.51 & 14.54 & 14.51 \\
\hline \multirow{3}{*}{5} & 1 & 15.15 & 15.23 & 15.3 & 15.29 & 15.67 & 15.328 \\
\hline & 2 & 15.67 & 15.78 & 15.88 & 15.65 & 15.8 & 15.756 \\
\hline & 3 & 15.17 & 15.2 & 15.1 & 15.22 & 15.14 & 15.166 \\
\hline \multirow{3}{*}{6} & 1 & 22.33 & 22.22 & 22.14 & 22.17 & 22.27 & 22.226 \\
\hline & 2 & 14.48 & 14.55 & 14.53 & 14.51 & 14.52 & 14.518 \\
\hline & 3 & 22.69 & 22.56 & 22.54 & 22.87 & 22.67 & 22.666 \\
\hline
\end{tabular}

Keterangan: Tile $1=$ Fullscreen

Tile $2=3$ Zona Kiri

Tile 3 = 3 Zona Kanan

\section{KESIMPULAN}

Hasil Pengujian sistem menunjukan kinerja yang sesuai dengan sasaran operasional yang diinginkan. Berdasarkan hasil pengujian ini juga dapat disimpulkan bahwa Program untuk Mendeteksi Gangguan dan Mengoreksi Format Tampilan Video Wall telah berhasil direalisasikan dalam perancangan ini sesuai dengan sasaran yang dirancang.

\section{DAFTAR PUSTAKA}

[1]. S.Robert, Videowalls - The Book of the Big Electronic Image. London: Focal Press,1997. p.24.

[2]. Suntec Singapore Wins New Guinness World Record, Febuari 8, 2014. http://www.suntecsingapore.com/suntec-singapore-wins-new-guinness-world-record/

[3]. Extron Electronics. Extron Videowalls System Design Guide. California: Extron Electronics, 2012. h.37-39. 